ISSN:1308-8173

Recieved: 06.10 .2021
E-ISSN: $1308-8505$

Accepted: 04.11.2021
Year: 2022

Published Online: 02.03.2022

RESEARCH ARTICLE
Vol: 37 No: 1 Pages: 250-268

Doi: $10.24988 /$ ije. 1005608

\title{
Technological Achievement of the World: An Update and Analysis of Countries, Continents and Periods
}

\author{
Büşra AĞAN 1
}

\begin{abstract}
This study examines the development of Technology Achievement Index for 72 nations from 1990 through 2019. The nations in the TAI are classified into four groups of countries and the determinants of TAI are comprised of creation of technology, diffusion of old technology, diffusion of new technology, and development of human skills for three periods of time. The main findings indicate that TAI ranking consists of leaders who are 9 countries, potential leaders are 43 countries, dynamic adopters are 5 countries, and only 5 countries are marginalized. In general, the findings show that leaders of TAI have capabilities to enable and use technology in three periods. Besides, over the past decades, the number of countries entering the ranks of potential leaders has observed an increase. Additionally, the empirical findings demonstrate that there is a statistically significant relationship between four sub-indices and has a positive correlation. This study, therefore, provides on the role of technological achievements, diffusions, and adaptions in the development of countries on the basis of four sub-indices, income levels, and time.
\end{abstract}

Keywords: Technology Achievement Index, Technology Diffusion, Technology Creation, Human Skills

Jel codes: 031, 033, 050

\section{Dünya'nın Teknolojik Başarısı: Ülkelerin, Kıtaların ve Dönemlerin Güncellenmesi ve Analizi}

\section{Özet}

Bu çalışma, 1990-2019 döneminde 72 ülke için Teknoloji Başarı Endeksinin gelişimini incelemektedir. TAI'deki ülkeler dört grup ülke halinde sınıflandırılır ve TAI'nin belirleyicileri üç zaman diliminde teknolojinin yaratılması, eski teknolojinin yayılması, yeni teknolojinin yayılması ve insan becerilerinin geliştirilmesinden oluşmaktadır. Ana bulgular, TAI sıralamasının 9 ülke liderlerden oluştuğunu, potansiyel liderlerin 43 ülke olduğunu, dinamik benimseyenler 5 ülke olduğunu ve sadece 5 ülkenin marjinalleştiğini göstermektedir. Genel olarak bulgular, TAI liderlerinin teknolojiye üç dönemde de erişme ve kullanma yeteneklerine sahip olduğunu göstermektedir. Ayrıca, son on yılda, potansiyel liderler sıralamasına giren ülkelerin sayısında bir artış gözlemlendi. Ek olarak, ampirik bulgular, dört alt endeks arasında istatistiksel olarak anlamlı bir ilişki olduğunu ve pozitif bir korelasyona sahip olduğunu göstermektedir. Dolayısıla bu çalışma, dört alt endeks, gelir düzeyi ve zaman bazında ülkelerin kalkınmasında teknolojik başarıların, yayılmaların ve adaptasyonların rolünü sunmaktadır.

Anahtar Kelimeler: Teknoloji Başarı Endeksi, Teknoloji Yayılımı, Teknoloji Yaratma, Insan Becerileri Jel Kodu: 031, 033, 050

ATIF ÖNERÍsí (APA): Ağan, B. (2022). Technological Achievement of the World: An Update and Analysis of Countries, Continents and Periods. İzmir Íktisat Dergisi. 37(1). 250-268. Doi: 10.24988/ije.1005608

${ }^{1}$ Research Assistant., Eastern Mediterranean University, Faculty of Business and Economics, Economics, Famagusta via Mersin 10, EMAIL: busra.agan@emu.edu.tr ORCID: 0000-0003-1485-9142. 


\section{INTRODUCTION}

Recently, the technological changes and the connectedness of global markets have increased the relationship between adaptation and the creation of technological innovations among nations. In general, technological adaptation and skills are critical to achieving substantive goals such as a pleasing standard of life or higher income. Technology is also a social phenomenon. The social system creates economic and political choices that affect the development and spread of technology. One of the important tools of technological development is the transfer of technology. This provides the transfer and comparison of technological developments in different countries, regions, sectors, industries, or businesses.

While a country can innovate in the current situation, it must further accelerate technological diffusion to provide the benefits. For the rapid diffusion of innovations, countries should increase their technology acquisition capabilities. There are several factors that affect a country's technological progress and achievements, besides many methods for measuring this success. Technology Achievement Index (TAI) is one of these methods. The TAI is involved in the 2001 Human Development Index, which is a compound index, evaluates the skills and capabilities of countries to attend in the network age. Furthermore, the first time this index has mainly proposed by Desai et al. in 2002. The TAI has handled calculation with four dimensions rather than direct measurement indicators. Each dimension of the TAI is found as taking an average of the indicator on that dimension. Therefore, this index supports global technology development of all nations' adaptation and improvement of technologies. Furthermore, it explains the creation of technology and the development of human skills. This index points that the nation's technological improvement depends on the nation's capability to utilize technology. The nations in the TAI also classified into four groups of countries as Leaders (TAI $>0.5)$, Potential Leaders ( $\mathrm{TAI}=0.35-0.49)$, Dynamic Adopters $(\mathrm{TAI}=$ 0.20-0.34), and Marginalized (TAI < 0.20) (Desai et al., 2002).

The portions of TAI comprise four main sub-groups and each sub-group is specified by two variables, also a total of eight indicators have the same weight in the mean of TAI. Those main sub-groups have consisted of creation of technology, diffusion of recent innovations, diffusion of old innovations, and the development of human skills. The four main sub-groups and each sub-group are summarized below:

- $\quad$ Creation of technology is measured by two sub-indicators patent grants by technology and receipts of royalties and license fees from abroad per capita. These sub-indicators represent nations' capacity for technology innovations and adaptation of technology processes.

- Diffusion of recent innovations consists of spreading of the internet hosts per 1000 people and medium-and-high technology exports as a share of all export. These sub-indicators offer improvement in the field of a division of the internet by users and creates dynamics of the global economy.

- $\quad$ Diffusion of old innovations is calculated by electricity consumption (kWh/capita) and telephones cellular and mainlines users per 1000 people. Technological improvement is an accumulated process and the wide diffusion of old technologies is needed for the adoption of the next technologies.

- Human skills are measured by gross enrolment in tertiary science and mean years of schooling received by people ages 15 and older. This indicator determines the number of youth and adults' technical and vocational skills, higher education skills in science, mathematics, engineering, and architecture in a country. 
The fundamental aim of TAI is to evaluate the technological skills, capabilities, and performances of a country in four dimensions with the level of development of a country. Therefore, this index focuses on the success and outcomes on four dimensions that are dependent on the creation of technology, the diffusion of recent and old innovations, and the human skills base.

The current literature in this field is quite limited. However, previous studies focus on the diffusion of technology and the ranking of TAI of countries. Hill and Dhanda (2003) investigate the links between the TAI and human development index among nations in order to be announced to the effects of the human rights society worldwide. The results show that Finland has the highest TAI while Mozambique has the lowest TAI among nations. Most research was associated the technology achievement index with other variables. Gani and Sharma (2003) explore the effectiveness of technological achievement and adaptation on rising Foreign Direct Investment among high-income nations using panel data from 1994 to 1998. Their conclusion reveals that a dynamic, competitive, and resilient environment gives chance to the creation of technology and innovation. On the other hand, Archibugi and Coco (2004) follow other similar studies to investigate and improvement of the TAI for a large number of countries, ranking technology index shows the highest value is in Singapore whereas the lowest value is in Ethiopia. Besides, they advocate the among indicators of technological creation can choose better resources of Research and Development (R\&D) than the combination of patents.

Some studies have compared the technology achievement index with other calculated indices and approaches or with the technology achievement index calculated in previous years. Arcelus et al. (2005) explain the nature of the TAI and Human Development Index (HDI) among countries, findings show the HDI and TAI show similar information effectiveness and produce similar country rankings and both give similar measures of economic and social well-being. Another study by Cherchye et al. (2008) use the TAI to capture the creation and dissemination of new or existing technologies in a country and the establishment of a human skills base for technology creation, in order to help legislators, define technology strategies in the data envelopment analysis (DEA) approach. Furthermore, Nasir et al. (2011) investigate the technological performance of 91 countries using Technology Achievement Index (TAI-09) based on a comparison with the calculated TAI-02 by Desai et al. Their results indicate that South Korea has the highest TAI value while Cambodia has the lowest value among 91 countries. Additionally, Ali et al. (2014) examine the impacts of technological improvement on 34 Muslim countries calculating the Technology Achievement Index (TAI-13) with the data of 2012 and also discuss various policy choices for the countries characterized in the study as potential leaders, dynamic adopters, and marginalized countries. Their findings indicate Muslim countries have a slow technology diffusion. Lastly, Incekara et al. (2017) analyse the Technology Achievement Index (TAI-16) calculated for 105 countries' technological improvement using standard deviation approach the data of 2015 with eight sub-indicators. Their findings show that Switzerland has the highest value as a leader whereas developing country Ethiopia has the lowest value on their calculation ranking.

In some studies, the technology achievement index calculated on cross country is associated with trade and growth on a macro basis. Gani (2009) analyses the links between high technology exports and economic growth in classified countries such as leaders, potential leaders, dynamic adopters and marginalized with respect to TAI. The empirical findings give strong evidence of the positive effect of high technology exports on per capita growth. Likewise, Burinskiene (2013) examine the links between international trade and models of technological innovations among nations. The empirical results indicate that in recent decades, technology leaders have had a great ability to employ improved trade technology. Recently, Ratnapuri and Inayati (2019) examine the gaps between countries that use the technical achievement index as the main indicator and vehicle and analyse how the differences occur. Their findings indicate that Singapore continues to lead in the TAI within all 
countries, contrary to other countries of South East Asia, while East Timor ranks lowest in the overall ranking.

This paper contributes and extends to the current literature in several ways. First of all, the main contribution of the literature is to investigate the analysis of the country groups and the crosscontinental groups in the graph and on the maps and tables with updated variables and datasets, and extended time-varying values. After that, summary statistical values are analysed according to income level and classification between continents, and it has been investigated whether there are correlations between the four main indicators in the measurement of TAI. Therefore, to analyse the technological abilities and performance of the world, TAI is measured among 72 selected countries for the period of 1990-2019.

Factors such as the speed of the technology diffusion process, the number of adopters of old and new innovations, and the education level of the society are important for the high technology achievement index among countries. TAI indicates a country's ability to create, adaptation and diffusion of technology and having a human skills base. Therefore, this study aims to analyse the development of technological achievement and adaptation across selected countries of the world.

In the process of TAI, countries are classified as higher, upper, and lower middle income and evaluate in nine-years three terms. TAI is calculated in four sub-indices yearly data from 1990 to 2019. This study extends time-varying values of TAI for 30 years and integrates with different categorizations of countries and continents. In these years, leaders are composed of 9 countries, potential leaders are from 43 countries, dynamic adopters are from 5 countries, and only 5 countries are marginalized. Calculations of TAI across countries results show that the overall ranking of the TAI starts at the average value of 0.831 in the United States and ends at the average value of 0.143 in Myanmar. The TAI rankings of first and second-order did not change in the high-income distribution of the United States and Japan and between the three periods.

The next part is focused on the empirical analysis of TAI and four sub-indices. Summary statistics for the period of 1990-2019 are examined according to income groups and geographic groups regarding the classification. The empirical results indicate that high-income countries have a higher adaptation on technologies and diffusion of innovations when compare with other income-level of countries. Moreover, the mean of four sub-indicators is shown that the mean of development of human skills (HSI) is greater in all income groups. However, the covariance coefficients between four sub-indices show a positive relationship between all dimensions and have the same direction. These results demonstrate that there is a statistically significant relationship between these indices and has a positive correlation. Summary, this study analyses the integration between education, telecommunication, the number of applied patents, technology exports, electricity consumption among 72 nations during recent years.

Following the introduction, the rest of the paper is continued as follows. Section 2 presents methodology and dataset while section 3 indicates an empirical analysis across countries, continents, and periods. Section 4 represents estimation results and explanations that finally, section 5 is composed of the conclusion part.

\section{METHODOLOGY AND DATA}

Most local and global information is important to need to be taken to improve technological progress in world countries. The speed of information transfer, the spread and development of technologies, and the adaptation of countries to technology are among the development indicators of countries around the world. Therefore, the factors behind the technological adaptation have been discussed with the income levels and time dimension of their countries. 
The purpose of this study evaluates the technological abilities in cross-country with time-varying datasets. Therefore, the method in this study is to calculate the TAI between selected countries. The pioneering study by Desai et al. (2002) is used to calculate the TAI. The calculation of TAI is composed of four major dimensions and eight sub-indicators of these dimensions, the dimensions of the indicators are averaged according to the selected variables. The indicators for each dimension are given the same weight. In the final indicator of TAI, dimensions are taken a quarter of the weight. Furthermore, TAI is derived as an index related to the minimum and maximum values observed by all the countries with data are chosen as indicators for each variable in these dimensions. The performance of each indicator is calculated separately the following general formula is applied.

$$
T A I=\frac{(\text { actual value }- \text { observed minimum value })}{(\text { observed maximum value }- \text { observed minimum value })}
$$

According to the formula of TAI, the output of each index of countries is expressed as a value between 0 and 1 . Therefore, the TAI summarizes the technological achievements of society and permits countries to makes technology and innovation levels comparable. When the index value of a country is close to 1 , this situation makes it reach a more leading position among others.

This study is covered from 1990 to 2019 annual time series which yields a panel dataset of 72 countries presented Table 1A in Appendix. In the study, the time span is split into three periods (1990-2000-2010). Due to the calculation of TAI, all eight indicators are collected for 72 countries. Since data availability did not exist in all countries. In addition, countries are classified as having a higher, upper, and lower middle income. Several databases in different organizations are used for the collection of variables. First, two indicators are used to examine the creation of technology are patent grants by technology are obtained by World Intellectual Property Organization (WIPO) statistics data centre and receipts of royalties and license fees are taken from World Development Indicators over the period of 1990-2019. The second part in indicators are used for the diffusion of recent innovations are internet hosts per 1000 people is obtained from World Development Indicators in World Bank and medium-and-high technology exports are also collected from World Development Indicators during the period of 1990-2019.

The third part of indicators are utilized for the diffusion of old innovations are by electricity consumption (kWh/capita) is obtained from World Development Indicators and the data of telephones cellular and mainline (per 1000 people) is collected from International Telecommunication Union (ITU). Besides, the fourth part of indicators has consisted of human skills are measured by gross enrolment in tertiary science is taken from World Development Indicators and mean years of schooling received by people ages 15 and older are extracted from Human Development Reports database. Finally, the overall index of TAI is estimated by taking averages of the values of all four sub-indicators. The progress of all estimated indices over the period of 19902019 for 72 countries is shown in Figure 1.

Next, the study aims to rank all countries among sub-indicators with their mean values of TAI. In order to do so, in the process of TAI, countries are classified as higher, upper-middle, and lowermiddle-income levels and also according to seven continents. Firstly, the classification of the TAI graph by income level of countries is as illustrated in Figure 2. It shows the continuously increasing process of TAI among all countries concerning income level and time-varying.

Secondly, the classification of the TAI graph by seven continents over the period of 1990-2019 is shown in Figure 3. In all three terms, some continents are observed to close each other during the time progress of TAI. 
Figure 1. All Estimated Indices for the period of 1990-2019

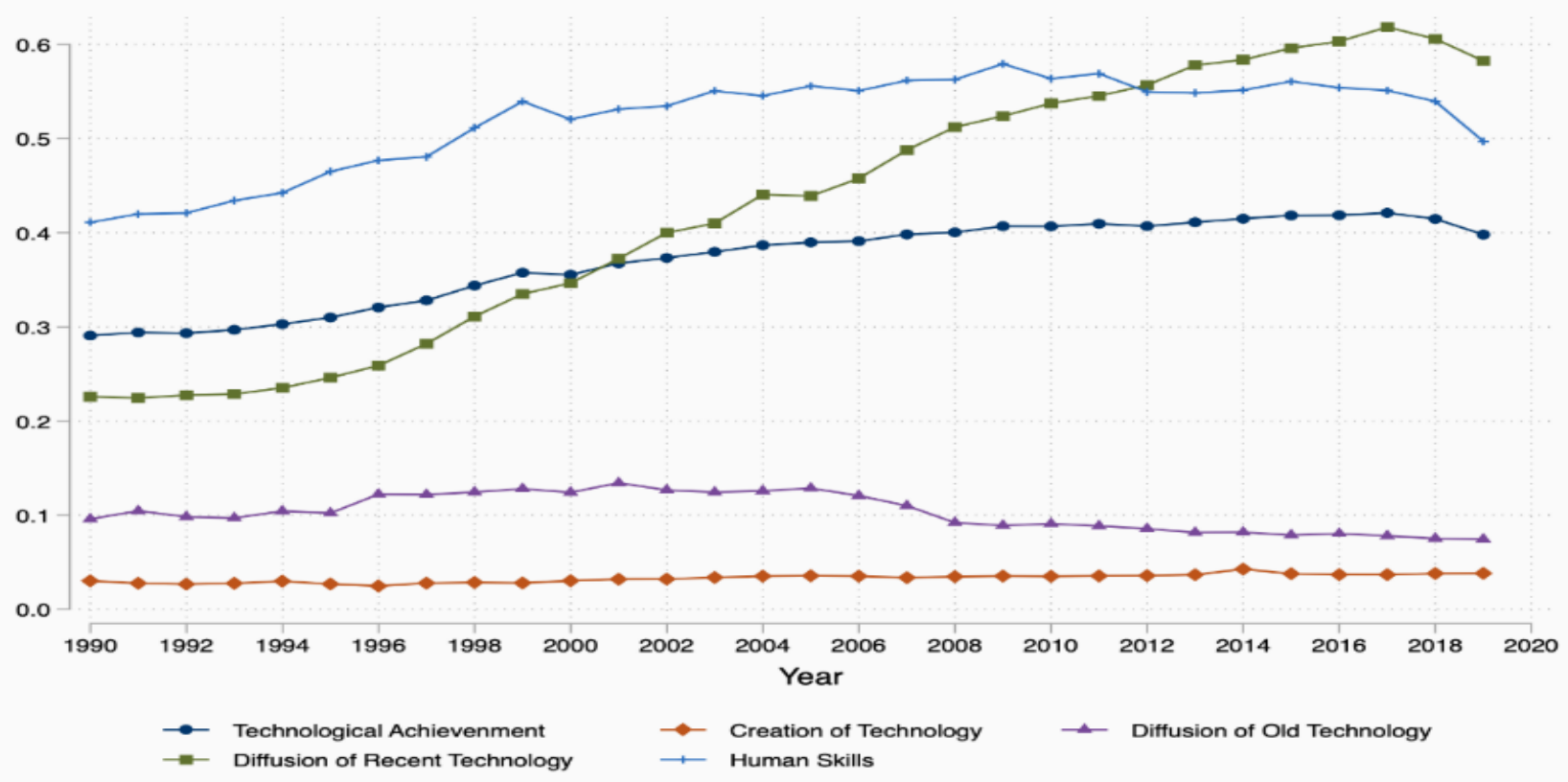

Source: Developed by the author.

Figure 2. Technology Achievement Index on average in all countries

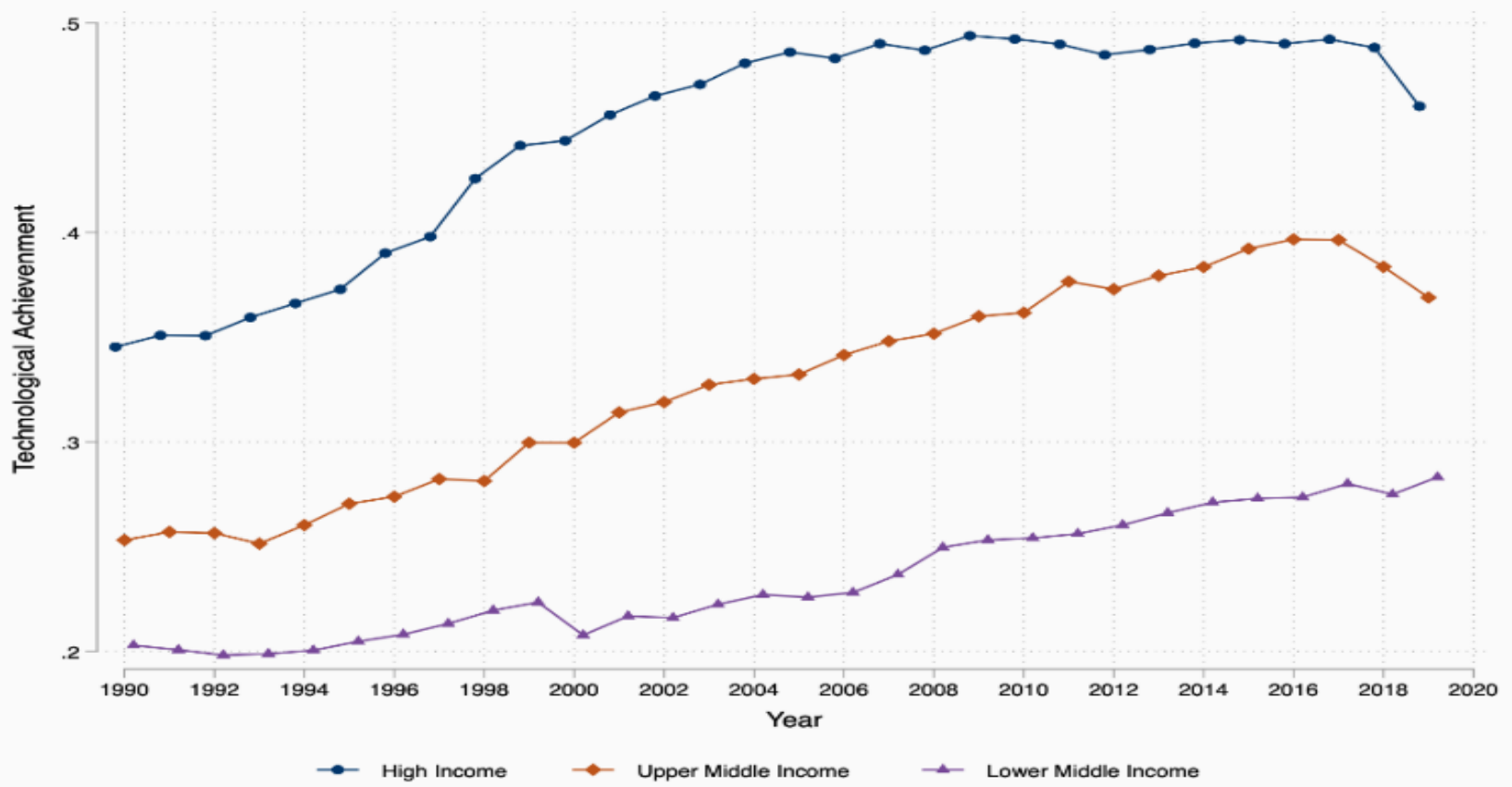

Source: Developed by the author. 
Figure 3. Technology Achievement Index in all continents

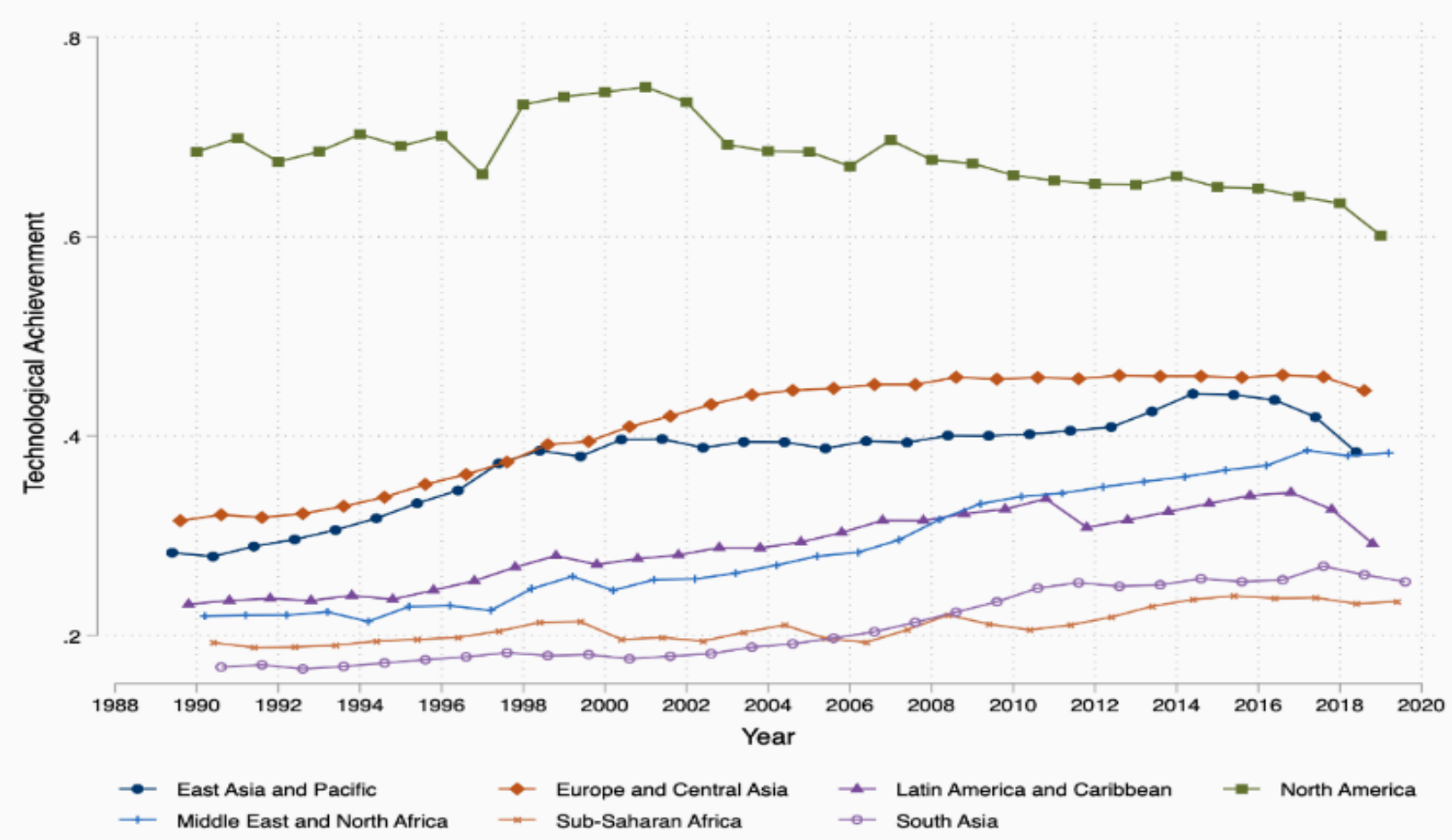

Source: Developed by the author.

\section{AN EMPIRICAL ANALYSIS ACROSS COUNTRIES, CONTINENTS AND PERIODS}

TAI is calculated for 72 countries using the contribution of Desai et al. (2002). Previous studies concentrated on comparison the values between two or more years of TAI. This study extends this concept with time-varying values of TAI within 30 years and integrates with different categorizations of countries and continents. Table $1 \mathrm{~B}$ in the appendix shows the overall TAI by calculating the average of all corresponding sub-indices and TAI rankings of 72 countries. Also, the value of the TAI is classified according to nine-year three terms from 1990 to 2019 and the income level of each country.

In overall TAI classification, the leaders are composed of 9 countries which start with the United States and the second rank is in Japan, followed by Norway, Sweden, Canada, Iceland, United Kingdom, Finland, and Germany. Following this, 43 countries were classified as potential leaders that started in the Netherlands and ended in Turkey. Another categorization is dynamic adopters consisted of 5 countries which are Moldova at the top and El Salvador at the bottom. Finally, the marginalized countries' ranking is made up of 5 countries which are ranked with Ghana first and Myanmar ranked last. However, the United States has become the first rank in all nine-years three terms when compared to other countries. Likewise, Japan is in the second rank in three-term. After the overall ranking of TAI, the rank has been separated according to nine- year three terms classification and income levels of the countries. According to the value of TAI of the countries, as in the original paper of Desai et al. (2002) the categorization of 72 countries was made as follows: If TAI is higher than 0.5 which is called Leaders (TAI > 0.5), if TAI is between 0.35 and 0.49 , it is called a Potential Leaders (TAI $=0.35-0.49$ ), if TAI is between 0.20 and 0.34 is called Dynamic Adopters (TAI $=0.20-0.34)$, and if TAI is less than 0.20 , Marginalized countries $(\mathrm{TAI}<0.20)$ are . 
In the first term from 1990 to 1999, there are four countries that are categorized as leaders, twenty countries are categorized as potential leaders, dynamic adopters have mostly consisted of thirtyeight countries. Also, the rest ten countries are ranked as marginalized. In the second term from 2000 to 2009, there are thirteen countries categorized as leaders, and also thirty countries categorized as potential leaders. Twenty-four countries are categorized as dynamic adopters and just five countries are ranked as marginalized. In the third term between 2010-2019 seventeen countries are categorized as leaders, thirty-five countries are ranked as potential leaders. There are seventeen countries also categorized as dynamic adopters and just three countries are ranked as marginalized when to compare others.

Based on the categorization of income levels, the United States ranked first among high-income countries in 1990-1999. However, Saudi Arabia ranked last. This ranking continued between the periods 2000 and 2009. In the last term from 2010 to 2019, the United States ranked first, while Uruguay took place last. In terms of upper-income level, Belarus ranked first in 1990-1999 and Georgia ranked last. In the second period from 2000 to 2009, Russia was on the top of the list, while Peru ranked last compared to other countries. In the final stage of 2010-2019, China took first place and Peru again took place at last rank. The categorization of the low-income level, Tajikistan took place in the first rank, while Myanmar ranked last. However, in the second period from 2000 to 2009 Ukraine was on the top of the list and Myanmar again took place last. In the final period of 20102019, Ukraine continued ranked first, while Senegal took place at last rank. Each category is explained in more detail below according to the average of TAI in three-term and all calculations have been completed by the author.

\section{Leaders (TAI is greater than 0.5):}

In the first period from 1990 to 1999, United States, Japan, Norway, and Canada are leaders in technological achievement. The US is top-ranked in all periods, hence making it the best country in North America. Japan takes place second rank after the US, so becoming the best country among East Asia \& Pacific countries. It has been followed by Norway and Canada, respectively which are among East Asia \& Pacific and North American countries. The US leads in the creation of technology, diffusion of old technology, and development of human skills indicator than Japan. However, Japan has a higher level of diffusion of recent innovations with the highest level of high and medium technology export and internet hosts. On the other hand, Canada has the highest level of creation of technology in three terms than Norway. Also, Norway takes place first in the diffusion of old technology, development of human skills, but for the diffusion of recent innovations, it has the first rank only in the second term between 2000-2009. In the second term also, Sweden, Iceland, the UK, Finland, Germany, Netherlands, Switzerland, France, and Denmark are added to the leader category. Besides, in the third term from 2010 to 2019, four more countries like China, Austria, Slovenia, Czechia are added to the leadership list respectively. After Japan, another East Asia \& Pacific country showed extremely rising performance in the creation of technology and diffusion of old innovations. Europe \& Central Asia region has gradually increased in the second and third periods.

\section{Potential Leaders (TAI is between $0.30-0.49$ ):}

The categorization of potential leaders for three periods is in the first term starts with Sweden and ends with Spain. Most European \& Central Asia countries are ranked as potential leaders. Israel has rapidly risen in the development of human skills and to be the most excellent among the Middle East \& North African countries for ranking TAI. In the second term, Slovenia is top-ranked as potential leader, Bulgaria and Mexico are ranked last. Despite the highest diffusion of old innovations in Australia and the highest human skills index in New Zealand, Slovenia is still considered a potential leader. However, Estonia is ranked first among European \& Central Asia countries in the third term 
as a potential leader, Liechtenstein takes place last. Also, Singapore has the highest rank in the diffusion of recent innovations among all potential leaders.

\section{Dynamic Adopters (TAI is between 0.20 - 0.34):}

Thirty-eight countries such as Tajikistan, Ukraine, Poland, Lithuania, Singapore, Czechia, Hungary, and up to Sri Lanka come under the Dynamic Adapters category in the first term. Poland and Ukraine have high technology creation while Italy has a high level of old technological innovations among Europe \& Central Asia countries. Also, Russia and Ukraine have the top of the human skill index in this period. In the second term from 2000 to 2009, twenty-four countries like the Philippines, Romania, Georgia, Tajikistan, Thailand, Brazil are categorized as Dynamic Adapters. Brazil has the highest rank in the diffusion of old innovations among Latin America \& Caribbean countries while Georgia has the top of the human skill index among Europe \& Central Asia countries. Also, the Philippines is ranked first in the diffusion of recent innovations among East Asia \& Pacific countries. The seventeen countries such as Colombia, Tajikistan, South Africa, Uruguay, India, Tunisia are classified as Dynamic Adapters in the third term. Saudi Arabia is the top of diffusion of recent innovations among the Middle East \& North Africa countries while India has the highest rank in the creation of technology among South Asia countries.

\section{Marginalized (TAI is less than 0.20):}

The Marginalized countries categorization consist of ten countries in the first term starts with Tunisia, Georgia, Morocco and ends with Myanmar. Two South Asia countries as India and Pakistan are in the group. And also, three Sub-Saharan African countries Ghana, Kenya, and Senegal are ranked in this group. In the second term, just five countries are ranked as Marginalized countries as Ghana, Kenya, Senegal among Sub-Saharan African countries, and also Pakistan and Myanmar are included in the group. These countries take place behind technological success for all indicators. The level of technological achievement in this group of countries is relatively low, and they are far away from technology creation and development of human skills. Even, these countries are trying reach to old innovations. Three countries such as Pakistan, Senegal, and Myanmar come under the marginalized countries in the third term. These countries have low skills for the creation of technology and diffusion of old and recent innovations.

Moreover, this study contributes to mapping the average values of the TAI from 1990 to 2019 among 72 countries which are shown in Figure 3. It compares to 72 nations through a global map considering their ranking on a TAI. In the map below, the higher values are represented by the darker blues, the lower values by the lighter blues.

As shown in Figure 4, 5, 6, and 7 the distribution of the four indicators used to measure TAI of 72 countries is shown on the map. To compare four indicators among selected countries, the color scale shows the degree to which countries are in the category. Darker blue in color scale starts with a higher degree of technology achievement and goes to the lighter blue which indicates a lower degree of technology achievement. The creation of technology index by countries is shown in Figure 4 . This index has two dimensions which are degreed according to which country is most successful in patent grants and receipts of royalties and license fees. In figure 5 shows the diffusion of old innovations index by countries on the map. This index is measured by electricity consumption and the number of cellular and mainline users, hence indicates to which country performed well in this index. 
Figure 3. Mapping of Countries by Technology Achievement Index

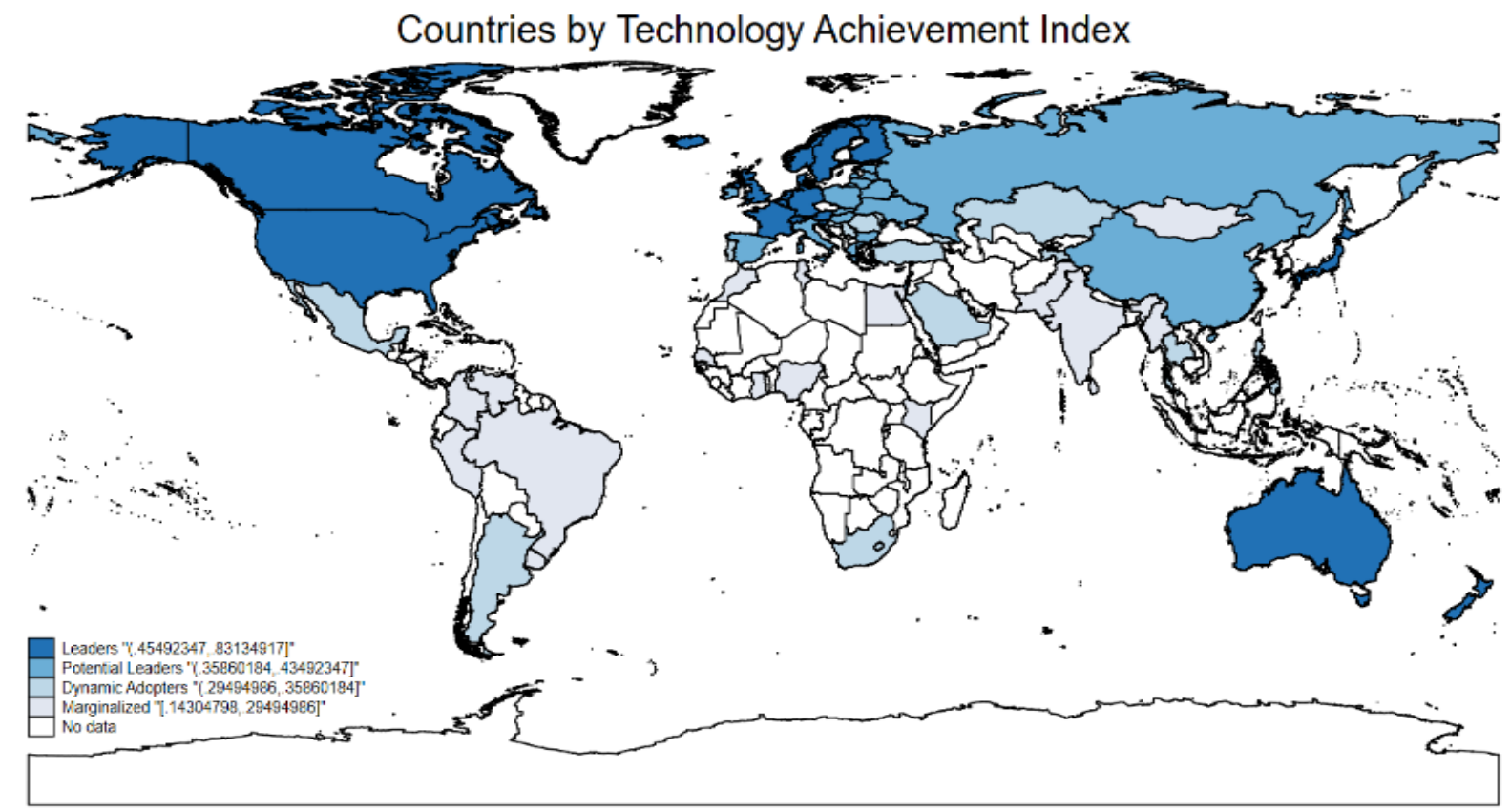

Source: Developed by the author.

Figure 4. Mapping of Countries by Creation of Technology

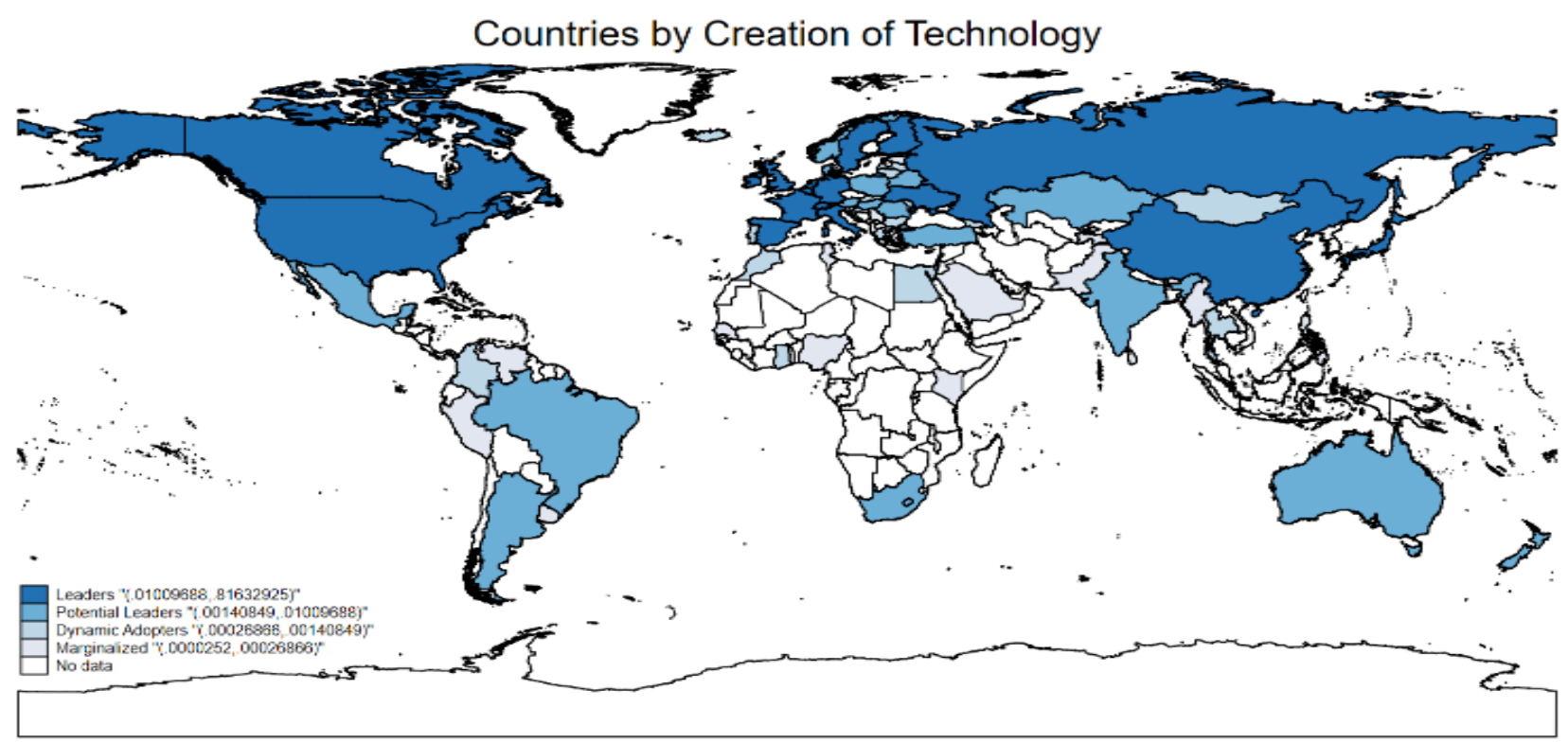

Source: Developed by the author. 
Figure 5. Mapping of Countries by Diffusion of Old Innovations

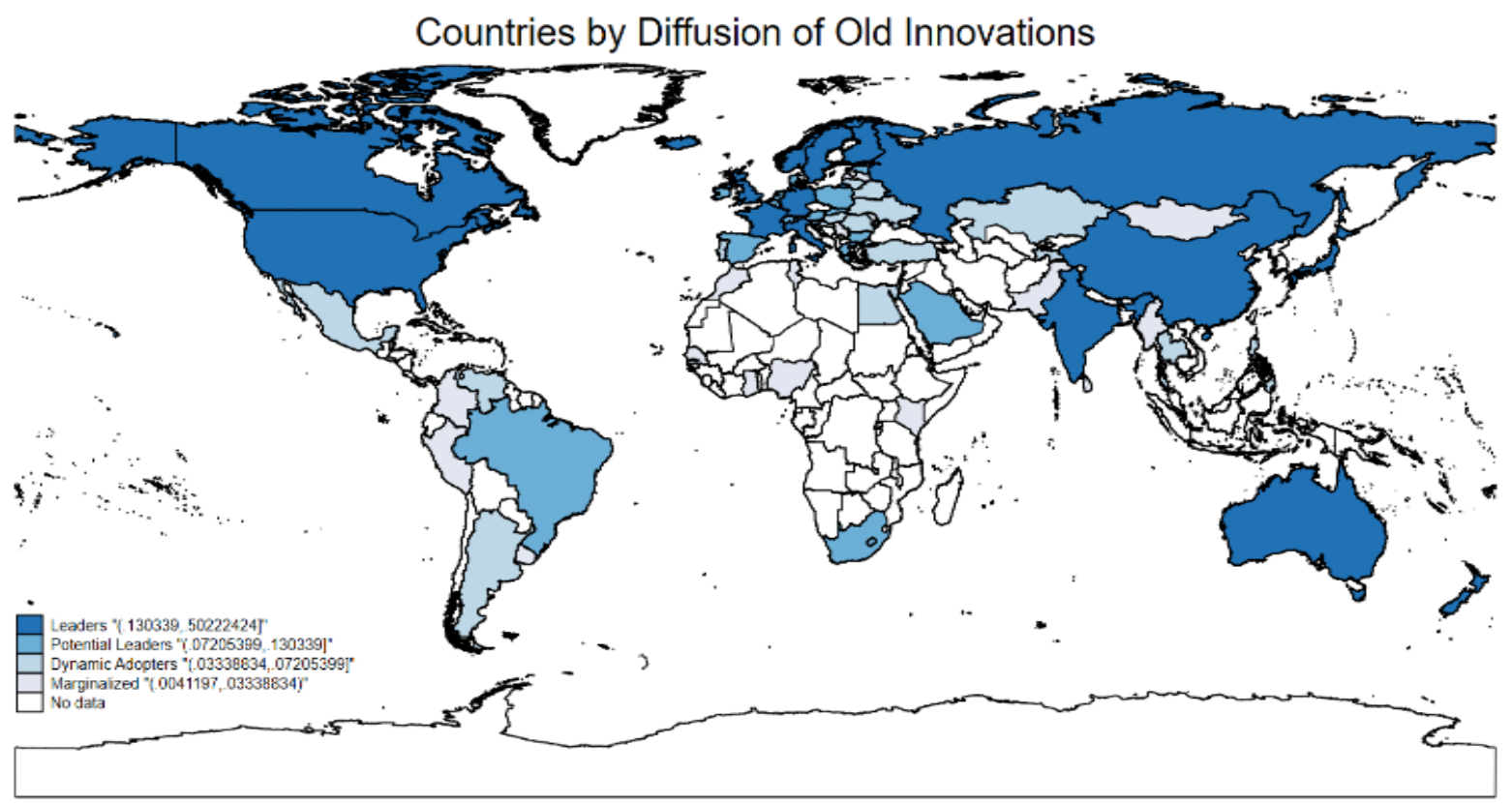

Source: Developed by the author.

A map of the diffusion of recent innovations by all countries is displayed in Figure 6 . It has been calculated by the number of internet users and medium-and-high technology exports. Therefore, most successful countries in the adaptation of recent technologies are degreed in the map with the color scale.

Figure 6. Mapping of Countries by Diffusion of Recent Innovations

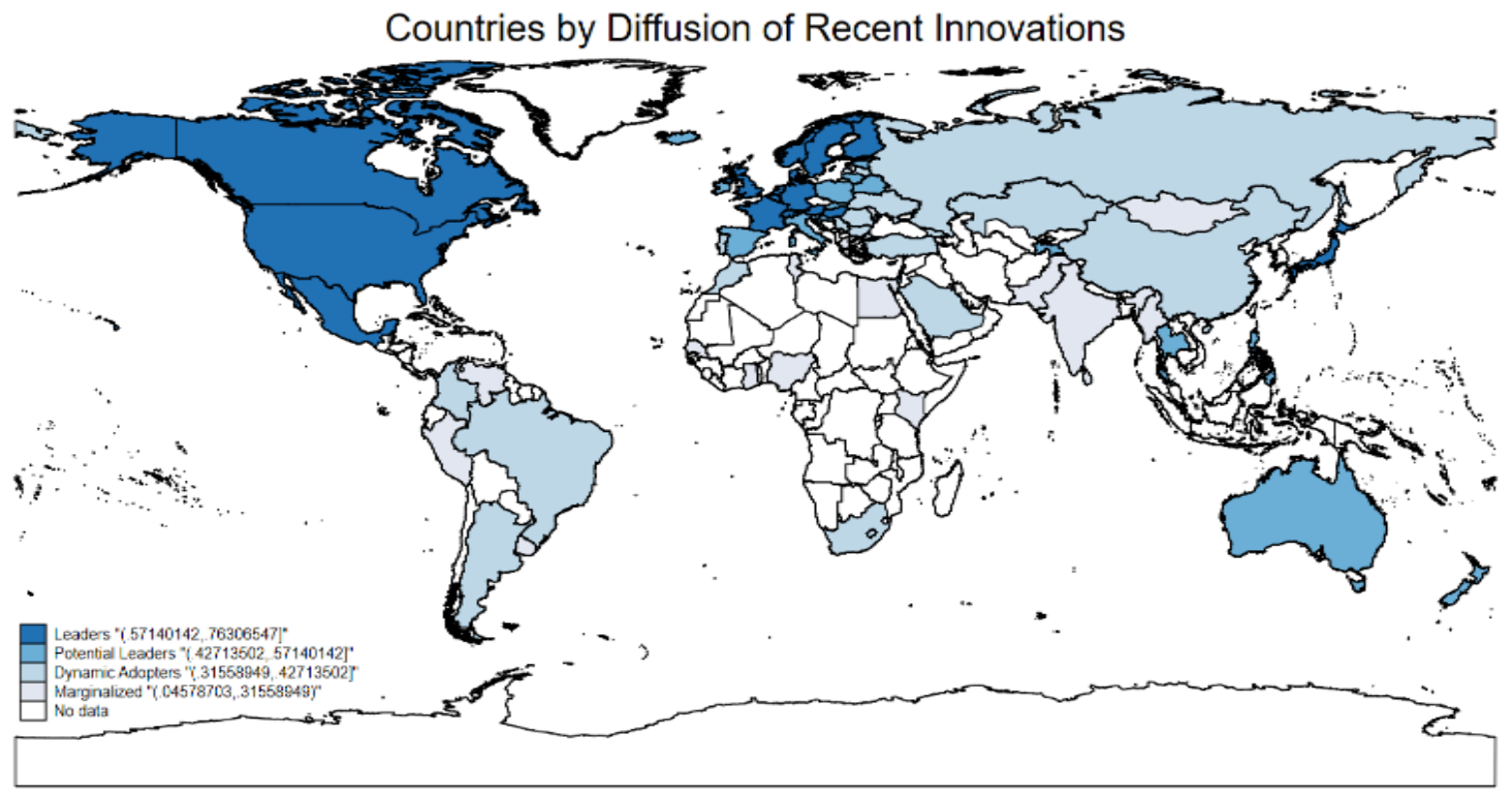

Source: Developed by the author.

Another indicator of TAI is the development of human skills by countries is shown on the map in Figure 7. This indicator is handled by the numbers of gross enrollment in tertiary science and mean 
years of schooling received by people ages 15 and older. As seen on the map, countries are degreed according to their success in the development of human skills.

Figure 7. Mapping of Countries by Human Skills

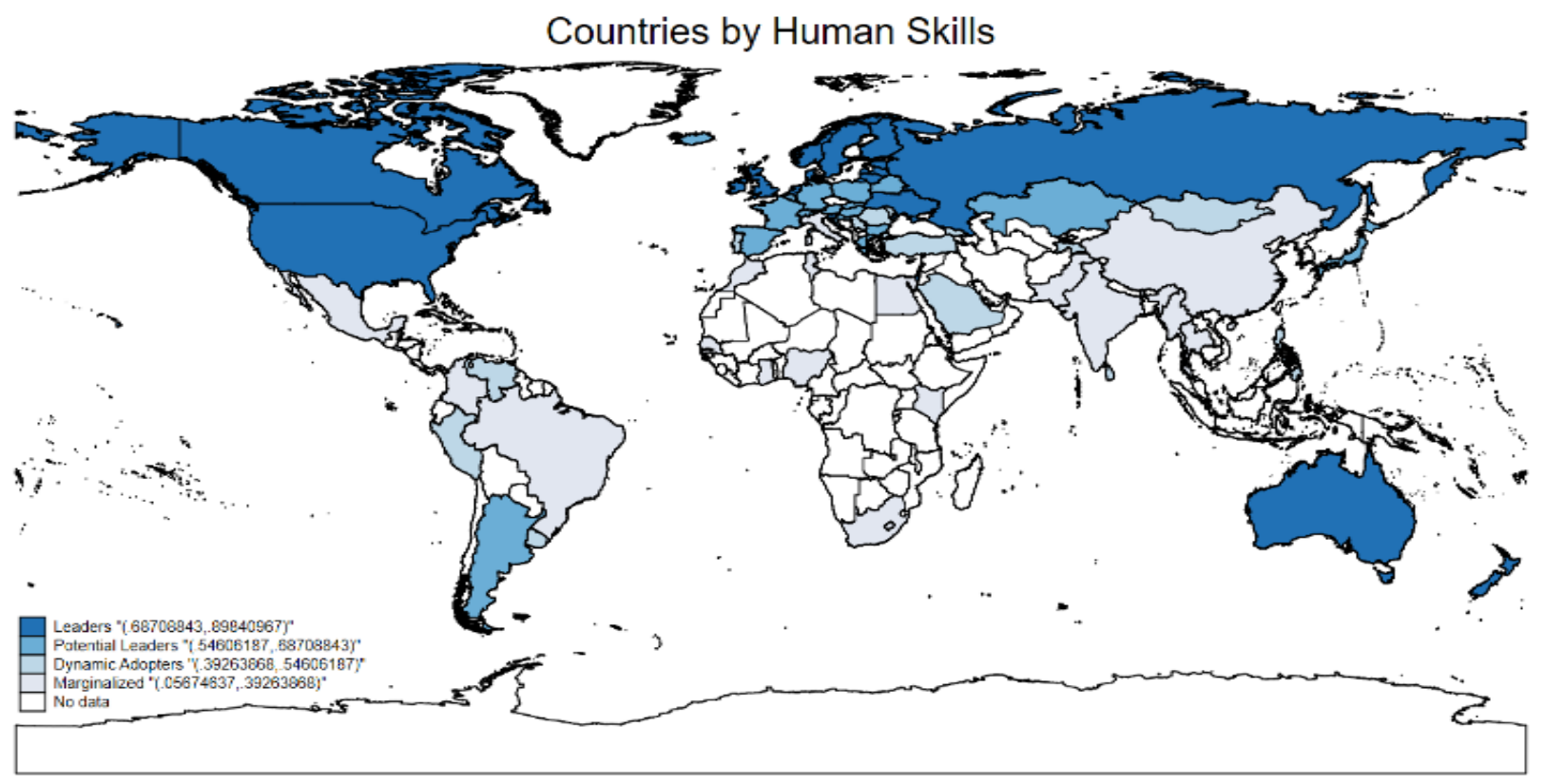

Source: Developed by the author.

\section{ESTIMATION RESULTS AND EXPLANATIONS}

In this section, summary statistics estimations are given for TAI and four sub-indicators. First of all, the summary statistics for the period of 1990-2019 are examined according to income levels of countries and grouping of continents regarding the classification we made. Secondly, summary statistical values of the four indicators are given and their correlations have been examined the degree of relationship between them. Summary statistics by income groups are reported in Table 3. The mean of TAI among the three income levels is greater in the higher-income level countries. On the other hand, the mean of four sub-indicators is represented that the mean of development of human skills (HSI) is greater in all income groups, this is followed by the diffusion of recent innovations (DRI), diffusion of old innovations (DOI), and creation of technology (CTI).

A lower standard deviation describes that the variables are closer to the mean, while a higher value of standard deviation means that the variables are rather farther apart. First of all, the mean and standard deviation of high-income countries are greater than upper-middle-income and lowermiddle-income countries. Secondly, the standard deviation of the higher income countries is lower in the diffusion of old innovations than the creation of technology, development of human skills, and the diffusion of recent innovations respectively. Also, the standard deviation of upper-middle-income countries is lower in the creation of technology than other sub-indicators. Similarly, lower-middleincome countries have a lower standard deviation in the creation of technology. The findings show that countries of different income levels have a different speed of adaptation to technologies and diffusion of innovations. 
Table 3: Summary Statistics by Income Group

\begin{tabular}{|c|c|c|c|c|c|c|c|c|c|}
\hline & $\mathbf{N}$ & Mean & Median & Max & Min & SD & CV & Skewness & Kurtosis \\
\hline & \multicolumn{9}{|c|}{ High Income } \\
\hline TAI & 1140 & 0.447 & 0.445 & 0.920 & 0.208 & 0.117 & 0.261 & 0.864 & 4.925 \\
\hline CTI & 1140 & 0.055 & 0.004 & 1.000 & 0.000 & 0.158 & 2.865 & 3.981 & 18.447 \\
\hline DOI & 1140 & 0.145 & 0.107 & 0.786 & 0.002 & 0.126 & 0.868 & 2.181 & 8.683 \\
\hline DRI & 1140 & 0.549 & 0.566 & 0.974 & 0.000 & 0.232 & 0.422 & -0.280 & 1.980 \\
\hline \multirow[t]{2}{*}{ HSI } & 1140 & 0.641 & 0.670 & 0.987 & 0.236 & 0.160 & 0.250 & -0.270 & 2.343 \\
\hline & \multicolumn{9}{|c|}{ Upper Middle Income } \\
\hline TAI & 540 & 0.327 & 0.329 & 0.620 & 0.152 & 0.080 & 0.243 & 0.507 & 3.359 \\
\hline CTI & 540 & 0.014 & 0.001 & 0.503 & 0.000 & 0.060 & 4.250 & 6.611 & 49.908 \\
\hline DOI & 540 & 0.077 & 0.055 & 0.544 & 0.000 & 0.097 & 1.264 & 3.727 & 17.466 \\
\hline DRI & 540 & 0.352 & 0.297 & 0.854 & 0.016 & 0.190 & 0.541 & 0.543 & 2.381 \\
\hline \multirow[t]{2}{*}{ HSI } & 540 & 0.467 & 0.438 & 0.833 & 0.000 & 0.168 & 0.360 & 0.088 & 2.267 \\
\hline & \multicolumn{9}{|c|}{ Lower Middle Income } \\
\hline TAI & 480 & 0.235 & 0.214 & 0.427 & 0.114 & 0.076 & 0.322 & 0.675 & 2.418 \\
\hline CTI & 480 & 0.001 & 0.000 & 0.048 & 0.000 & 0.004 & 3.864 & 7.374 & 65.511 \\
\hline DOI & 480 & 0.033 & 0.016 & 0.459 & 0.000 & 0.062 & 1.868 & 4.911 & 29.015 \\
\hline DRI & 480 & 0.218 & 0.169 & 0.788 & 0.003 & 0.171 & 0.784 & 0.998 & 3.252 \\
\hline HSI & 480 & 0.288 & 0.238 & 0.843 & 0.019 & 0.175 & 0.607 & 0.940 & 3.371 \\
\hline
\end{tabular}

Source: Calculated by author on STATA program.

The summary statistics of the geographic group are reported as illustrated in Table 4. First of all, the mean of TAI among the seven continents is greater in North America and Europe and Central Asia than in others for the period of 1990-2019. This in fact is expected due to the fact that the process of development among continents in the field of education, telecommunication, the number of applied patents, technology exports, electricity consumption during the recent years increases. Secondly, the mean of four sub-indicators is indicated that the mean of development of human skills (HSI) is higher in all geographic groups, except for Sub-Saharan Africa, followed by the diffusion of recent innovations (DRI), diffusion of old innovations (DOI), and creation of technology (CTI). Also, the creation of technology in North America has a higher standard deviation while other continents have a lower standard deviation in the creation of technology. On the other hand, except for South Asia and North America, other continents have a higher standard deviation on the diffusion of recent innovations. These findings show that the technology capacity of the countries is developing and the technology is spreading among the nations.

Technology achievements of countries are based on four indicators is composed of two variables. In table 5 is reported the summary statistics which is related to the average of the four indices. The mean of creation of technology index (CTI) has a lower average when compared with other subindices whereas the mean of human skills index (HSI) has a higher average value. And also, the means of the other indicators are ordered as diffusion of recent innovations index (DRI) and diffusion of old innovations index (DOI) respectively. 
Table 4: Summary Statistics by Geographic Group

\begin{tabular}{|c|c|c|c|c|c|c|c|c|c|}
\hline & $\mathbf{N}$ & Mean & p50 & Max & Min & SD & CV & Skewness & Kurtosis \\
\hline \multicolumn{10}{|c|}{ East Asia and Pacific } \\
\hline TAI & 270 & 0.376 & 0.365 & 0.727 & 0.114 & 0.152 & 0.404 & 0.420 & 2.732 \\
\hline CTI & 270 & 0.084 & 0.001 & 0.660 & 0.000 & 0.191 & 2.283 & 2.145 & 5.918 \\
\hline DOI & 270 & 0.130 & 0.080 & 0.544 & 0.000 & 0.145 & 1.116 & 1.712 & 5.179 \\
\hline DRI & 270 & 0.422 & 0.492 & 0.974 & 0.003 & 0.270 & 0.640 & 0.013 & 2.071 \\
\hline HSI & 270 & 0.470 & 0.431 & 0.969 & 0.051 & 0.227 & 0.483 & 0.347 & 2.296 \\
\hline \multicolumn{10}{|c|}{ Europe and Central Asia } \\
\hline TAI & 1200 & 0.412 & 0.408 & 0.641 & 0.152 & 0.095 & 0.231 & -0.002 & 2.395 \\
\hline CTI & 1200 & 0.019 & 0.002 & 0.200 & 0.000 & 0.037 & 1.991 & 2.478 & 8.501 \\
\hline DOI & 1200 & 0.111 & 0.079 & 0.519 & 0.000 & 0.100 & 0.905 & 2.172 & 8.231 \\
\hline DRI & 1200 & 0.498 & 0.488 & 0.916 & 0.000 & 0.235 & 0.471 & -0.016 & 1.809 \\
\hline HSI & 1200 & 0.620 & 0.636 & 0.976 & 0.000 & 0.151 & 0.244 & -0.507 & 3.295 \\
\hline \multicolumn{10}{|c|}{ Latin America and Caribbean } \\
\hline TAI & 240 & 0.289 & 0.278 & 0.444 & 0.194 & 0.064 & 0.222 & 0.623 & 2.460 \\
\hline CTI & 240 & 0.001 & 0.000 & 0.005 & 0.000 & 0.001 & 1.356 & 1.576 & 4.687 \\
\hline DOI & 240 & 0.047 & 0.038 & 0.146 & 0.002 & 0.034 & 0.721 & 1.111 & 3.770 \\
\hline DRI & 240 & 0.312 & 0.258 & 0.854 & 0.037 & 0.184 & 0.588 & 0.736 & 2.833 \\
\hline HSI & 240 & 0.394 & 0.373 & 0.734 & 0.155 & 0.135 & 0.341 & 0.724 & 3.025 \\
\hline \multicolumn{10}{|c|}{ North America } \\
\hline TAI & 60 & 0.681 & 0.618 & 0.920 & 0.440 & 0.159 & 0.234 & 0.157 & 1.315 \\
\hline CTI & 60 & 0.421 & 0.350 & 1.000 & 0.015 & 0.403 & 0.957 & 0.057 & 1.082 \\
\hline DOI & 60 & 0.396 & 0.348 & 0.786 & 0.158 & 0.201 & 0.507 & 0.751 & 2.289 \\
\hline DRI & 60 & 0.688 & 0.763 & 0.853 & 0.357 & 0.160 & 0.232 & -0.977 & 2.375 \\
\hline HSI & 60 & 0.821 & 0.873 & 0.987 & 0.425 & 0.138 & 0.168 & -1.538 & 5.000 \\
\hline \multicolumn{10}{|c|}{ Middle East and North Africa } \\
\hline TAI & 150 & 0.290 & 0.271 & 0.497 & 0.157 & 0.098 & 0.339 & 0.575 & 2.288 \\
\hline CTI & 150 & 0.001 & 0.000 & 0.008 & 0.000 & 0.002 & 1.646 & 1.625 & 4.036 \\
\hline DOI & 150 & 0.057 & 0.037 & 0.142 & 0.007 & 0.044 & 0.773 & 0.537 & 1.718 \\
\hline DRI & 150 & 0.335 & 0.281 & 0.850 & 0.059 & 0.221 & 0.659 & 0.634 & 2.238 \\
\hline HSI & 150 & 0.369 & 0.317 & 0.797 & 0.114 & 0.202 & 0.548 & 0.842 & 2.541 \\
\hline \multicolumn{10}{|c|}{ Sub-Saharan Africa } \\
\hline TAI & 150 & 0.210 & 0.195 & 0.364 & 0.137 & 0.054 & 0.260 & 0.962 & 3.178 \\
\hline CTI & 150 & 0.001 & 0.000 & 0.013 & 0.000 & 0.002 & 2.217 & 3.429 & 16.637 \\
\hline DOI & 150 & 0.028 & 0.009 & 0.125 & 0.002 & 0.035 & 1.262 & 1.343 & 3.451 \\
\hline DRI & 150 & 0.208 & 0.192 & 0.585 & 0.016 & 0.127 & 0.610 & 0.940 & 3.654 \\
\hline HSI & 150 & 0.201 & 0.195 & 0.421 & 0.019 & 0.101 & 0.501 & 0.212 & 2.727 \\
\hline \multicolumn{10}{|c|}{ South Asia } \\
\hline TAI & 90 & 0.209 & 0.194 & 0.359 & 0.137 & 0.056 & 0.269 & 1.001 & 3.191 \\
\hline CTI & 90 & 0.002 & 0.000 & 0.012 & 0.000 & 0.003 & 1.572 & 2.037 & 6.986 \\
\hline DOI & 90 & 0.075 & 0.014 & 0.459 & 0.004 & 0.127 & 1.687 & 1.980 & 5.338 \\
\hline DRI & 90 & 0.121 & 0.109 & 0.370 & 0.026 & 0.075 & 0.615 & 1.192 & 4.108 \\
\hline HSI & 90 & 0.239 & 0.178 & 0.447 & 0.070 & 0.124 & 0.520 & 0.471 & 1.579 \\
\hline
\end{tabular}

Source: Calculated by author on STATA program.

Table 5: Summary Statistics on Four Sub-indices

\begin{tabular}{cccccc}
\hline Variable & Obs. & Mean & Std. Dev. & Min. & Max. \\
\hline TAI & 72 & 0.3701 & 0.1331 & 0.1144 & 0.9201 \\
\hline CTI & 72 & 0.0328 & 0.1184 & 0.0002 & 0.8163 \\
\hline DOI & 72 & 0.1029 & 0.1025 & 0.0041 & 0.5022 \\
\hline DRI & 72 & 0.4257 & 0.1852 & 0.0458 & 0.7631 \\
\hline HSI & 72 & 0.5193 & 0.1964 & 0.0567 & 0.8984
\end{tabular}

Source: Calculated by author.

Lastly, Table 6 indicates the covariance analysis among four indices of calculation TAI. A higher correlation occurs between diffusion of recent technology and development of human skill 
dimensions, on the other hand, creation of technology and development of human skills dimensions have a lower correlation. According to the covariance coefficients between four sub-indices, there is a positive relationship between all dimensions, they move in the same direction. These results demonstrate that there is a statistically significant relationship between these indices at $1 \%$ significance level and has a positive correlation.

Table 6: Covariance / Correlation Analysis among Sub-Indices

\begin{tabular}{|c|c|c|c|c|}
\hline \multicolumn{5}{|c|}{ Covariance / Correlation } \\
\hline Var & CTI & DOI & DRI & HSI \\
\hline \multirow{2}{*}{ CTI } & 0.01383 & & & \\
\hline & $(1.0000)$ & & & \\
\hline \multirow[t]{2}{*}{ DOI } & 0.00687 & 0.01038 & & \\
\hline & $(0.5735)^{*}$ & $(1.0000)$ & & \\
\hline \multirow[t]{2}{*}{ DRI } & 0.00792 & 0.01026 & 0.03385 & \\
\hline & $(0.3662)^{*}$ & $(0.5474)^{*}$ & $(1.0000)$ & \\
\hline \multirow[t]{2}{*}{ HSI } & 0.00627 & 0.00939 & 0.02489 & 0.03806 \\
\hline & $(0.2732)^{*}$ & $(0.4725)^{*}$ & $(0.6933)^{*}$ & $(1.0000)$ \\
\hline
\end{tabular}

Source: Calculated by author.

Note: Correlations are in parentheses and $*$ denotes significance at $1 \%$ level.

\section{CONCLUSION}

The importance of technological innovation in the competition of globalized countries has become increasingly prominent, and the difference in competitiveness depends to a large extent on technological innovation. This paper aims to provide empirical evidence on the development of Technology Achievement Index (TAI) across countries of the world. Therefore, the concept of TAI and its calculation with four sub-dimensions has been explained at the global level. In this framework, the technological innovation performances of the countries are compared for a large number of countries and for three periods of time. In particular, a comparison of countries in four different dimensions is provided. These dimensions include covering the technology creation capacity of countries, the diffusion of old technologies, adaptation to new technologies, and human skills such as education level. In order to do so, the analysis used yearly data from 1990 to 2019 on the calculation of TAI. The main contribution is to extend the time-varying values of TAI for 30 years and is integrated with different categorizations of countries and continents. According to the value of TAI of the countries, 72 countries are categorized. In the first term between 1990-1999, there are thirty-eight countries mostly dynamic adopter countries, the second term from 2000 to 2009 there are thirty countries categorized mostly as potential leaders, and lastly the third term between 2010 2019 there are thirty-five countries are ranked mostly as potential leaders.

The main findings indicate that TAI ranking consists of leaders who are 9 countries, potential leaders are 43 countries, dynamic adopters are 5 countries, and only 5 countries are marginalized. Additionally, the overall TAI ranking starts with the United States in the first place and ends with Myanmar in the last place. Northern America and Europe lead by the development of TAI. The mean and standard deviation of high-income countries are greater than upper-middle-income and lowermiddle-income countries. Therefore, high-income countries have a higher adaptation on technologies and diffusion of innovations when compare with other income-level of countries. Likewise, the mean of four sub-indicators is shown that the mean of development of human skills (HSI) is greater in all income groups. The findings indicate that countries of different income levels have a different speed of adaptation to technologies and diffusion of innovations. The empirical 
analysis also shows that a higher correlation occurs between diffusion of recent technology and development of human skill dimensions, on the other hand, creation of technology and development of human skills dimensions have a lower correlation. These results demonstrate that there is a statistically significant relationship between four sub-indices and has a positive correlation. This in fact is expected due to the fact that the diffusion among continents integrations between in the field of education, telecommunication, the number of applied patents, technology exports, electricity consumption during the recent years increases.

In conclusion, it is worth pointing out that this study attempts to provide new evidence on the development of the Technology Achievement Index across selected countries of the world. Moreover, the distribution of TAI in the world and the technological development by countries make inferences about the situation of technology adoption and reflect the GDP, trade, investments, and the level of development of a country. The empirical analysis is examined to countries into three groups. All selected countries have been analysed with comparable results on the determinants of TAI. The results give evidence that technological performance and capabilities are stable in a high-income country. On the rank of TAI, when considered together with the economic, social, and socio-economic factors, some countries are ranked high, while some countries are in the last rank. Therefore, it provides the opportunity to compare the level of development of each country based on its ability to produce and use technology. Leaders of TAI have huge capabilities to enable technology to be applied in three periods. Besides, over the past few decades, the number of countries entering the ranks of potential leaders has observed an improvement.

The policy implication of this study is that countries in potential leaders, dynamic adopters, and marginalized categorizes need to grow up adaptation of technology and also produce and trade technology-specific products in order to include among the leading countries. Therefore, countries should have and improve the technological capabilities in the field of creation of technology, human skills, diffusion of old technologies, and diffusion of new technologies. These major fields consist of many alternatives such as investments in R\&D, increase schooling ratio, human capital formation, developing new technological products, and open technology trading. Furthermore, government and policymakers should encourage the producers and contribute new possibilities for individuals in order to produce and trade technological products in the international areas. 


\section{REFERENCES}

Ali, T.M., Kiani, A.K., Asrar, M., Bashir T., 2014, “Technology Achievement Index of Muslim Nations-Ranking and Comparative Study" Science, Technology and Development, Vol: 33, (2), pp. 49-62.

Arcelus, F., Sharma, B., \& Srinivasan, G. (2005). Assessing the information content of the technology achievement index in the presence of the human development. Economics Bulletin, 15(1).

Archibugi, D., \& Coco, A. (2004). A new indicator of technological capabilities for developed and developing $\begin{array}{llll}\text { countries (ArCo). World } \quad \text { bevelopment, } & \text { 32(4), }\end{array}$ https://doi.org/10.1016/j.worlddev.2003.10.008.

Burinskiene, A. (2013). International Trade, Innovations, and Technological Achievement in Countries.795-812. https://doi.org/10.2507/daaam.scibook.2013.48

Cherchye, L., Moesen, W., Rogge, N., Van Puyenbroeck, T., Saisana, M., Saltelli, A., Liska, R., \& Tarantola, S. (2008). Creating composite indicators with DEA and robustness analysis: The case of the Technology Achievement Index. Journal of the Operational Research Society, 59(2), 239-251. https://doi.org/10.1057/palgrave.jors.2602445

Desai, M., Fukuda-Parr, S., Johansson, C., \& Sagasti, F. (2002). Measuring the Technology Achievement of Nations and the Capacity to Participate in the Network Age. Journal of Human Development, 3(1), 95122. https://doi.org/10.1080/14649880120105399

Gani, A. (2009). Technological Achievement, High Technology Exports and Growth. Journal of Comparative International Management, 12(2), 31.

Gani, A., \& Sharma, B. (2003). The effects of information technology achievement and diffusion on foreign direct investment. Perspectives on Global Development and Technology, 2(2), 161-178. https://doi.org/10.1163/156915003322763548

Hill, R. P., \& Dhanda, K. K. (2003). Technological achievement and human development: A view from the United Nations Development Program. Human Rights Quarterly, 25(4), 1020-1034. https://doi.org/10.1353/hrq.2003.0044

Incekara, A., Guz, T., \& Sengun, G. (2017). Measuring the technology achievement index: comparison and ranking of countries. Pressacademia, 164-174. https://doi.org/10.17261/pressacademia.2017.446

Nasir, A., Ali, T. M., Shahdin, S., \& Rahman, T. U. (2011). Technology achievement index 2009: Ranking and comparative study of nations. Scientometrics, 87(1), 41-62. https://doi.org/10.1007/s11192-0100285-6

Ratnapuri, C. I., \& Inayati, T. (2019). Technology Gaps among South East Asia Countries from the Perspective of Technology Achievement Index. International Journal of Recent Technology and Engineering, 8(4), 500-505.https://doi.org/10.35940/ijrte.d6916.11841 
Table 1A: List of Countries

\section{APPENDIX}

\begin{tabular}{llll}
\hline Argentina & Australia & Austria & Belarus \\
\hline Belgium & Brazil & Bulgaria & Canada \\
\hline China & Colombia & Croatia & Cyprus \\
\hline Czechia & Denmark & El Salvador & Egypt \\
\hline Estonia & Finland & France & Ghana \\
\hline Georgia & Germany & Greece & Hungary \\
\hline Iceland & India & Ireland & Israel \\
\hline Italy & Japan & Kenya & Kazakhstan \\
\hline Liechtenstein & Lithuania & Luxembourg & Latvia \\
\hline Morocco & Mongolia & Moldova & Mexico \\
\hline Myanmar & Netherlands & Nigeria & Norway \\
\hline New Zealand & Pakistan & Peru & Philippines \\
\hline Portugal & Poland & Romania & Russia \\
\hline Saudi Arabia & Singapore & Sri Lanka & Serbia \\
\hline Senegal & Slovenia & Sweden & Slovakia \\
\hline Switzerland & South Africa & Spain & Tajikistan \\
\hline Turkey & Tunisia & Thailand & Ukraine \\
\hline US & UK & Uruguay & Venezuela \\
\hline
\end{tabular}

Source: Selected countries from World Bank Classification.

Table 1B: Technology Achievement Index in Three-Term with Sub-Indices and Rankings

\begin{tabular}{|c|c|c|c|c|c|c|c|c|c|c|c|c|c|c|c|c|c|}
\hline \multirow{2}{*}{\multicolumn{3}{|c|}{ TAI ranking in average three-term }} & \multirow{2}{*}{\multicolumn{3}{|c|}{$\begin{array}{l}\text { Technology } \\
\text { Achievement Index }\end{array}$}} & \multirow{2}{*}{\multicolumn{3}{|c|}{$\begin{array}{l}\text { Overall } \\
\text { TAI } \\
\text { Ranking in } \\
\text { three } \\
\text { terms }\end{array}$}} & \multicolumn{9}{|c|}{ Income-levels } \\
\hline & & & & & & & & & \multicolumn{3}{|c|}{$\begin{array}{l}\text { High- } \\
\text { income } \\
\text { countries }\end{array}$} & \multicolumn{3}{|c|}{$\begin{array}{l}\text { Upper- } \\
\text { middle } \\
\text { income } \\
\text { countries }\end{array}$} & \multicolumn{3}{|c|}{$\begin{array}{l}\text { Lower- } \\
\text { income } \\
\text { countries }\end{array}$} \\
\hline $\begin{array}{l}\text { TAI } \\
\text { rank }\end{array}$ & $\begin{array}{l}\text { Country- } \\
\text { name }\end{array}$ & $\begin{array}{c}\text { Overall } \\
\text { TAI }\end{array}$ & $\begin{array}{l}1990- \\
1999 \\
(1)\end{array}$ & $\begin{array}{c}2000- \\
2009 \\
(2)\end{array}$ & $\begin{array}{l}2010- \\
2019 \\
(3)\end{array}$ & (1) & (2) & (3) & (1) & (2) & (3) & (1) & (2) & (3) & (1) & (2) & (3) \\
\hline 1 & US & 0.831 & 0.870 & 0.868 & 0.757 & 1 & 1 & 1 & 1 & 1 & 1 & - & - & - & - & - & - \\
\hline 2 & Japan & 0.655 & 0.593 & 0.715 & 0.657 & 2 & 2 & 2 & 2 & 2 & 2 & - & - & - & - & - & - \\
\hline 3 & Norway & 0.565 & 0.529 & 0.615 & 0.552 & 3 & 3 & 5 & 3 & 3 & 4 & - & - & - & - & - & - \\
\hline 4 & Sweden & 0.538 & 0.482 & 0.596 & 0.536 & 5 & 4 & 9 & 5 & 4 & 8 & - & - & - & - & - & - \\
\hline 5 & Canada & 0.531 & 0.525 & 0.534 & 0.535 & 4 & 9 & 10 & 4 & 9 & 9 & - & - & - & - & - & - \\
\hline 6 & Iceland & 0.520 & 0.389 & 0.577 & 0.595 & 15 & 5 & 3 & 14 & 5 & 3 & - & - & - & - & - & - \\
\hline 7 & UK & 0.517 & 0.457 & 0.564 & 0.529 & 6 & 7 & 11 & 6 & 7 & 10 & - & - & - & - & - & - \\
\hline 8 & Finland & 0.513 & 0.439 & 0.573 & 0.528 & 8 & 6 & 12 & 8 & 6 & 11 & - & - & - & - & - & - \\
\hline 9 & Germany & 0.502 & 0.444 & 0.510 & 0.552 & 7 & 13 & 6 & 7 & 13 & 5 & - & - & - & - & - & - \\
\hline 10 & Netherlands & 0.497 & 0.410 & 0.537 & 0.537 & 12 & 8 & 8 & 11 & 8 & 7 & - & - & - & - & - & - \\
\hline 11 & Switzerland & 0.492 & 0.403 & 0.528 & 0.546 & 13 & 11 & 7 & 12 & 11 & 6 & - & - & - & - & - & - \\
\hline 12 & France & 0.484 & 0.424 & 0.512 & 0.516 & 10 & 12 & 14 & 10 & 12 & 14 & - & - & - & - & - & - \\
\hline 13 & Denmark & 0.478 & 0.384 & 0.534 & 0.517 & 17 & 10 & 13 & 16 & 10 & 13 & - & - & - & - & - & - \\
\hline 14 & Slovenia & 0.454 & 0.370 & 0.491 & 0.500 & 19 & 14 & 17 & 18 & 14 & 17 & - & - & - & - & - & - \\
\hline 15 & Belgium & 0.449 & 0.387 & 0.478 & 0.480 & 16 & 16 & 21 & 15 & 16 & 21 & - & - & - & - & - & - \\
\hline 16 & New Zealand & 0.444 & 0.401 & 0.485 & 0.446 & 14 & 15 & 28 & 13 & 15 & 28 & - & - & - & - & - & - \\
\hline 17 & Austria & 0.438 & 0.382 & 0.428 & 0.503 & 18 & 28 & 15 & 17 & 27 & 15 & - & - & - & - & - & - \\
\hline 18 & Australia & 0.435 & 0.436 & 0.451 & 0.418 & 9 & 22 & 36 & 9 & 22 & 12 & - & - & - & - & - & - \\
\hline 19 & Estonia & 0.435 & 0.343 & 0.472 & 0.488 & 24 & 17 & 18 & 22 & 17 & 18 & - & - & - & - & - & - \\
\hline
\end{tabular}




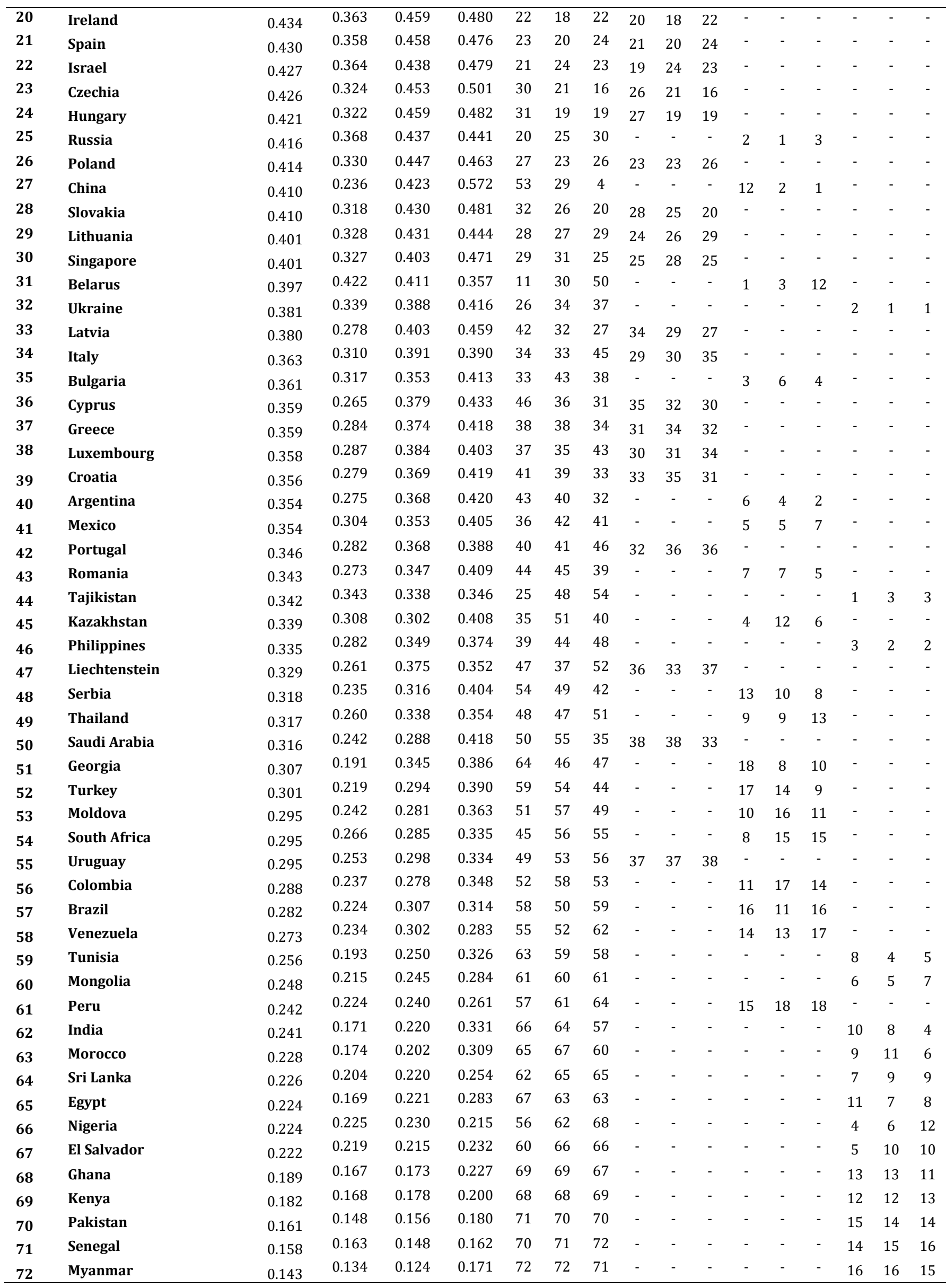

